\title{
Genetic and Phenotypic Relationships Among Locomotion Type Traits, Profit, Production, Longevity, and Fertility in Spanish Dairy Cows
}

\author{
M. A. Pérez-Cabal, ${ }^{1}$ C. García, O. González-Recio, and R. Alenda \\ Departamento de Producción Animal E.T.S.I. Agrónomos - Universidad Politécnica Ciudad Universitaria s/n 28040 Madrid, Spain
}

\begin{abstract}
The phenotypic and genetic relationships of 3 locomotion traits with profit, production, longevity, and fertility traits were studied to determine the importance of locomotion traits for dairy producers. Two data sets including official milk records and type classification scores of 62,293 cows, and reproductive records of 24,561 cows from the Basque and Navarra Autonomous Regions were analyzed. Higher scores for feet and legs (FL), foot angle (FA), and rear legs set (RLS) were positively related to production and functional traits, whereas fertility was not significantly affected. The cows that scored the highest for FL were $\$ 213 / y r$ more profitable, produced $575 \mathrm{~kg}$ more milk per year, and remained in the herd for 307 more functional days than the cows scoring the lowest. Feet and legs was the trait most genetically correlated to profit, although a low value (0.10) was obtained, whereas RLS was the trait most correlated to milk production (0.12). Genetic correlations among FL, FA, RLS, and longevity traits (from -0.10 to 0.05 ) were low. Quadratic curves were the best fit for both profit and functional herd life for EBV of each of the 3 locomotion traits. Further studies dealing with profitability and lameness, instead of using conformation traits, could be performed directly if a larger data pool of lameness was routinely recorded.
\end{abstract}

Key words: breeding value, locomotion, profit, genetic relationship

\section{INTRODUCTION}

Locomotion traits are one of the most important selection criteria for dairy breeders. An animal with bad locomotion will not easily gain access to feed and the milking parlor, and therefore, profitability, labor, and animal welfare will be affected (Warnick et al., 2001). Moreover, the high price of semen for sires with high breeding values for feet and legs reflects the importance given to this trait by dairy producers. Foot and leg

Received July 14, 2005.

Accepted December 11, 2005.

${ }^{1}$ Corresponding author: ma.perezcabal@upm.es morphology contributes to hoof erosion and locomotion diseases (Boelling and Pollott, 1998a), commonly leading to lameness.

Lameness produces direct and indirect economic losses (Boettcher et al., 1998). Direct costs are due to treatment dispensed and the involuntary culling of cows with chronic lameness. The National Animal Health Monitoring System (2002) reported a 16.3\% culling rate due to lameness, being the third most common reason for involuntary culling. However, lameness also contributes to other causes of culling, such as reproductive culls (Sattler, 2002). Booth et al. (2004) reported that lameness was associated with decreased survival, especially between 61 and 120 DIM or at the end of lactation. Indirect economic losses occur due to milk yield reduction and fertility deterioration. Green et al. (2002) estimated a $360-\mathrm{kg}$ reduction in milk yield per 305-d lactation. Kossaibati et al. (1999) reported an average direct cost of $£ 50$ per case of lameness and an extra $£ 86$ loss due to fertility in the United Kingdom. The cost of each case of lameness was estimated at $\$ 302$ in the United States (Sattler, 2002).

Several authors also have recorded lameness or locomotion scores in experimental settings to study relationships with conformation. Boettcher et al. (1998) found that foot angle (FA), rear leg set (RLS), and rump width were most highly correlated to clinical lameness. They also suggested that type traits could only provide an indication of susceptibility to locomotion diseases. Boelling and Pollott (1998a,b) found that some effects such as old age, deep udders, sickled legs, and long hoof diagonals tend to deteriorate locomotion. Results from Van Dorp et al. (2004) indicated that cows with better scores for feet and legs (FL), FA, RLS, and strong udder attachments had more favorable locomotion.

Lameness, foot and leg diseases, and locomotion scores are not routinely recorded on commercial farms. Recently, locomotion scores have been recorded in Spain, but data are insufficient for analysis. Thus, morphological traits related to locomotion such as FL, FA, and RLS were studied (Vollema and Groen, 1997; PérezCabal and Alenda, 2002). These traits have low heritabilities and low genetic correlations with profit (PérezCabal and Alenda, 2002) but positive relationships with 
longevity. Traditionally, type traits were thought to be linearly related to profit and longevity, but some studies showed significant quadratic relationships. Specifically, Norman et al. (1996) found phenotypic intermediate optima for FA and RLS, and Pérez-Cabal and Alenda (2002) reported quadratic curves from 3 locomotion traits in a study dealing with genetic relationships of 14 type-trait EBV with profit and longevity EBV.

To determine the importance of locomotion traits for dairy producers, the aims of this study were 1) to update the genetic parameters of 3 locomotion traits (FL, FA, and RLS) for a larger population and their genetic relationships with profit and longevity, but also with other traits such as production and fertility, and 2) to analyze the phenotypic relationships with longevity, production, fertility, and profit.

\section{MATERIALS AND METHODS}

\section{Data}

Official milk records and type classification scores (from 1979 to July 2003) and reproductive records (from 1986 to July 2003) of cows from the Basque and Navarra Autonomous Regions were provided by the corresponding Holstein Associations (EFRIFE and AFNA, respectively). The initial milk record file included 525,708 lactations of 186,877 cows distributed in 1,824 herds. The type classification file consisted of 112,166 scored cows. The reproductive file included inseminations of 120,713 cows. Original files were edited to obtain appropriate data sets for the statistical analyses. The requirements were that all animals had to belong to herds with continuous milk recording during a minimum of $3 \mathrm{yr}$ to have at least $3 \mathrm{yr}$ of productive life, to avoid censored data as much as possible. First calving was required to be before July 2000 for all cows and lactations had to be consecutive beginning with the first. Animals had to be between 18 and 40 mo at the age of first calving. Days in lactation had to range between 100 and $500 \mathrm{~d}$, and calving interval between 300 and $550 \mathrm{~d}$.

Three locomotive traits were studied: 2 standard linear traits (FA and RLS), scored from 1 to 9 , and a general characteristic (FL) classified into 6 main categories: poor $(\mathbf{P})$, fair $(\mathbf{F})$, good $(\mathbf{G})$, good plus $(\mathbf{G G})$, very good (VG), and excellent (EX), each of which had 3 subcategories. Thus, cows are classified into $18 \mathrm{FL}$ classes, but only the 6 main classes were analyzed in this study. Cows are scored once, preferably at first lactation (76\% of cows in the data) and if not possible, at second. Only cows from third lactation can be reclassified as EX.

Economic data used in this study were the average values for 1999 from 239 representative herds of Basque Autonomous Region, provided by EFRIFE man- agement services. Economic data considered were prices of milk and calves, feeding costs (for cows and heifers), and other costs such as housing and labor (Pérez-Cabal and Alenda, 2003). Based on 1999 prices, profit per cow per year (PROF) was calculated as the difference between income and costs for the entire productive life of each cow, and was expressed per year of productive life as described in Pérez-Cabal and Alenda (2002). In PROF calculations, actual milk yield was used, whereas for phenotypic and genetic studies, the production trait was 305-d kg of milk in first lactation (M305). Longevity traits included number of lactations, days of productive life (measured as days between first calving and the last day of the last lactation), and functional herd life (FHL), obtained as days of productive life adjusted by production level following Pérez-Cabal and Alenda (2003). Other traits analyzed were average DIM per lactation, percentage of DIM, (i.e., ratio between total DIM and days of productive life), and average dry days per lactation (DD). Average calving inter$\operatorname{val}(\mathbf{C I})$ and average number of inseminations per lactation (ANI) were considered as fertility traits.

For both phenotypic and genetic analyses, complete data for production, type classification, profit, longevity, and fertility were required. A total of 62,293 cows were used for analyses between locomotion traits and profit, production and longevity. Because reproductive data were fewer than milk records, analyses of fertility with type traits included only 24,561 cows.

\section{Phenotypic Analysis}

Phenotypic relationships were analyzed with the GLM procedure of SAS (SAS Institute, 2001). The following fixed model was applied for PROF, DD, and DIM:

$$
\mathrm{y}_{\mathrm{ij}}=\mathrm{HY}_{\mathrm{i}}+\mathrm{LT}_{\mathrm{j}}+\mathrm{e}_{\mathrm{ij}}
$$

For longevity and M305, fixed models were

$$
\mathrm{y}_{\mathrm{ijkl}}=\mathrm{HY}_{\mathrm{i}}+\mathrm{Mc}_{\mathrm{j}}+\mathrm{AFC}_{\mathrm{k}}+\mathrm{LT}_{\mathrm{l}}+\mathrm{e}_{\mathrm{ijkl}}
$$

For fertility traits, fixed models were

$$
\mathrm{y}_{\mathrm{ijkl}}=\mathrm{HY}_{\mathrm{i}}+\mathrm{Mc}_{\mathrm{j}}+\mathrm{LA}_{\mathrm{k}}+\mathrm{LT}_{\mathrm{l}}+\mathrm{e}_{\mathrm{ijkl}}
$$

where HY is fixed effect of herd-year of first calving $(7,263)$ levels, LT is each 1 of the 3 locomotion traits (FL, FA, or RLS), Mc is fixed effect of month of first calving (12 levels), AFC is fixed effect of age at first calving (4 levels: 18 to $24 \mathrm{mo}, 25$ to $28 \mathrm{mo}, 29$ to $33 \mathrm{mo}$, 34 to $40 \mathrm{mo}$ ), LA is fixed effect of lactation-age of cow (3 levels). Additional analyses with M305 as a covariate 
were performed for fertility traits and DD. Differences among the least squares means of FL, FA, and RLS classes were analyzed using Tukey's multiple means comparison test at 5\% significance level.

\section{Genetic Analysis}

Genetic parameters and EBV of PROF, production, longevity, and fertility traits were obtained by REML from bivariate analyses using the VCE 4.0 software (Groeneveld and García Cortés, 1998). All cows included had a known sire. The final pedigree file for estimation of breeding values contained 85,718 animals. The model analyzed for PROF, DD, and DIM was

$$
\mathrm{y}_{\mathrm{ij}}=\mathrm{HY}_{\mathrm{i}}+\mathrm{a}_{\mathrm{j}}+\mathrm{e}_{\mathrm{ij}}
$$

For longevity and M305, models were

$$
\mathrm{y}_{\mathrm{ijkl}}=\mathrm{HY}_{\mathrm{i}}+\mathrm{Mc}_{\mathrm{j}}+\mathrm{AFC}_{\mathrm{k}}+\mathrm{a}_{\mathrm{l}}+\mathrm{e}_{\mathrm{ijkl}}
$$

For fertility traits, models were

$$
\mathrm{y}_{\mathrm{ijkl}}=\mathrm{HY}_{\mathrm{i}}+\mathrm{Mc}_{\mathrm{j}}+\mathrm{LA}_{\mathrm{k}}+\mathrm{a}_{\mathrm{l}}+\mathrm{e}_{\mathrm{ijkl}}
$$

The model for locomotion traits was

$$
\mathrm{y}_{\mathrm{ijklm}}=\mathrm{HRC}_{\mathrm{i}}+\mathrm{LA}_{\mathrm{j}}+\mathrm{LS}_{\mathrm{k}}+\mathrm{a}_{\mathrm{l}}+\mathrm{e}_{\mathrm{ijklm}}
$$

where fixed effects were HY as herd-year of first calving (7,263 levels), Mc as month of first calving (12 levels), AFC as age at first calving (4 levels), HRC as herdround-classifier (7,357 levels), LA as lactation-age of cow (3 levels), and LS as lactation stage (11 levels). Random effects were animal (a) and residual term (e).

To determine whether the genetic relationships of locomotion traits with other traits were linear, regressions of EBV were performed. Linear and quadratic regressions of PROF EBV, M305, and FHL on each locomotion trait EBV from every animal with data (62,293 cows) were obtained using GLM procedures:

$$
\mathrm{EBV}_{\mathrm{y}}=\mu+\mathrm{a} \cdot \mathrm{EBV}_{\mathrm{LT}}\left(+\mathrm{b} \cdot \mathrm{EBV}_{\mathrm{LT}}^{2}\right)
$$

where $\mathrm{y}$ is PROF, M305, and FHL; LT is each of the 3 locomotion traits (FL, FA, and RLS); and a and b are the linear and quadratic coefficients, respectively. Coefficients of determination and cross validation were performed to determine whether the quadratic fit was better than the linear one. Profit adjusted for production was also performed, adding EBV of M305, 305-d kg of fat, and protein in first lactation as covariates in the model, to study profitability regardless of production.

\section{RESULTS AND DISCUSSION}

\section{Phenotypic Analysis}

Higher FL scores and intermediate FA and RLS scores were positively related to M305 and functional herd life. Only high FL scores affected cow fertility, but differences among FL classes disappeared when CI was adjusted by production. Other studies reported fertility deterioration among animals with good locomotion scores because of higher yield that could drive energetic disorders affecting reproductive ability (McDaniel, 1997; Sattler, 2002).

Feet and Legs. Least squares means of PROF, production, longevity, and fertility traits according to FL score are shown in Table 1 . Cows with higher FL scores were more profitable $(P<0.05)$, produced more milk, were more functional, and completed more lactations. Differences between a VG cow and a P cow were $\$ 211$ per year, $573 \mathrm{~kg}$ of milk of first lactation, and $307 \mathrm{~d}$ of FHL. In addition, \%DIM was significantly higher for cows with poor legs. This may be due to voluntary culling in first lactations of cows with bad leg conformation, and therefore, those cows would have fewer DD in their entire productive life (and per lactation). For instance, cows scored as P had 10 DD less than VG cows regardless of production. Average CI was shorter for lowscored cows, although no differences were found between classes P through GG. Moreover, after adjustment for milk production, FL did not have an effect on CI. Feet and legs score was not statistically significant for ANI, although figures showed a slightly positive trend.

It should be noted that only 82 cows were classified as EX. Those cows showed better performance in general than the rest of cows. However, only cows from third calving can be scored as EX, so results for that class can be biased and will not be further considered in the result comments.

Foot Angle. Least squares means of PROF, production, longevity, and fertility traits according to FA score are shown in Table 2. Higher FA scores resulted in more PROF and M305. However, few differences among FA classes were found, and results were not as clear as for FL groups. Differences between FA classes for $\% \mathrm{DIM}$ and DD were not significant. Longevity traits followed the same trend. Intermediate optima FA scores (6 and 7) were not statistically different from the highest scored cows for both FHL and number of lactations. Cows with a score of 8 had $108 \mathrm{~d}$ more FHL and 0.3 more lactations than cows with a score of 1 . Analyses for ANI and CI showed that those effects were not significant.

Rear Leg Set. Least squares means of PROF, production, longevity, and fertility traits according to RLS 
Table 1. Least squares means and sample size (n) of profit, production, longevity, and fertility traits ${ }^{1}$ according to feet and legs score

\begin{tabular}{|c|c|c|c|c|c|c|c|c|c|c|c|c|c|}
\hline $\begin{array}{l}\text { Feet } \\
\text { and } \\
\text { legs }^{2}\end{array}$ & \multicolumn{9}{|c|}{ Profit, production, and longevity traits } & \multicolumn{4}{|c|}{ Fertility traits } \\
\hline $\mathrm{P}$ & 1,221 & $-59^{f}$ & $5,518^{\mathrm{e}}$ & $1,216^{\mathrm{f}}$ & $3.2^{\mathrm{f}}$ & $321^{\mathrm{abc}}$ & $87.2^{\mathrm{a}}$ & $56^{\mathrm{e}}$ & $54^{\mathrm{d}}$ & 562 & $408^{\mathrm{b}}$ & 1.72 & $412^{\mathrm{al}}$ \\
\hline G & 28,058 & $35^{\mathrm{d}}$ & $5,775^{\mathrm{c}}$ & $1,364^{\mathrm{d}}$ & $3.6^{\mathrm{d}}$ & $319^{\mathrm{bc}}$ & $85.9^{\mathrm{c}}$ & $62^{\mathrm{c}}$ & $60^{\mathrm{b}}$ & 11,034 & $407^{\mathrm{b}}$ & 1.77 & $411^{b}$ \\
\hline GG & 17,730 & $86^{\mathrm{c}}$ & $5,927^{b}$ & $1,415^{\mathrm{c}}$ & $3.7^{\mathrm{c}}$ & $320^{\mathrm{a}}$ & $85.5^{\mathrm{d}}$ & $63^{\mathrm{b}}$ & $62^{\mathrm{a}}$ & 6,633 & $409^{b}$ & 1.79 & $413^{\mathrm{al}}$ \\
\hline VG & 2,445 & $151^{\mathrm{b}}$ & $6,091^{\mathrm{a}}$ & $1,523^{\mathrm{b}}$ & $4.0^{\mathrm{b}}$ & $321^{\mathrm{ab}}$ & $84.9^{\mathrm{e}}$ & $65^{\mathrm{a}}$ & $64^{\mathrm{a}}$ & 891 & $415^{\mathrm{a}}$ & 1.85 & $418^{\mathrm{a}}$ \\
\hline $\mathrm{EX}$ & 82 & $390^{\mathrm{a}}$ & $6,341^{\mathrm{a}}$ & $1,875^{\mathrm{a}}$ & $4.8^{\mathrm{a}}$ & $329^{\mathrm{ab}}$ & $84.1^{\mathrm{de}}$ & $58^{\text {abcde }}$ & $57^{\text {abcd }}$ & 21 & $416^{\mathrm{ab}}$ & 2.03 & $417^{\text {al }}$ \\
\hline
\end{tabular}

${ }^{\mathrm{a}-\mathrm{f}}$ Means within columns with different superscripts differ $(P<0.05)$.

${ }^{1}$ Traits: PROF = profit; M305 = 305-d milk yield in first lactation; FHL = functional herd life; NL = number of lactations; DIM = average DIM; \% DIM = percentage of DIM; DD = average dry days; $\mathrm{DD}_{a d j}=$ average dry days adjusted by production; CI = average calving interval; $\mathrm{ANI}=$ average number of inseminations per lactation; and $\mathrm{CI}_{a d j}=$ average calving interval adjusted by production.

${ }^{2}$ Feet and legs score: $\mathrm{P}=$ poor; $\mathrm{F}=$ fair; $\mathrm{G}=$ good; $\mathrm{GG}=$ good plus; $\mathrm{VG}=$ very good; $\mathrm{EX}=$ excellent.

${ }^{3}$ Residual standard deviation.

score are shown in Table 3. Results are in accordance with an intermediate optimum, because the most profitable, productive, and functional animals are cows scored 5 or 6 for RLS. Rear legs set score did not affect DIM, ANI, or CI. However, RLS was statistically significant in the ANOVA for DD, because the intermediate scores tended to have slightly longer dry periods, but no significant differences existed between RLS classes for DD, even after adjusting for production.

\section{Genetic Parameters}

Heritability. Heritabilities and genetic correlations for locomotion traits, PROF, M305, longevity, and fertility traits shown in Table 4 are in accordance with literature references. Feet and legs, FA, and RLS had low heritabilities $(0.14,0.12$, and 0.19 , respectively) although they had significant variability, as reported by other authors (Jairath et al., 1998; Pérez-Cabal and Alenda, 2002; Fatehi et al., 2003).

Profit had a lower heritability (0.20) than the value obtained by Pérez-Cabal and Alenda (2002) for a similar population. Heritability for M305 was 0.34 , similar to previous estimates from Spain. Longevity traits, PL and FHL, had an estimated heritability of 0.10 , slightly higher than values reported by Pérez-Cabal and Alenda (2002). Both fertility traits (CI and ANI) had heritabilities of 0.04, similar to most studies dealing with reproductive ability (Smith et al., 1998; Pryce et al., 2000; Veerkamp et al., 2001; González-Recio and Alenda, 2005), despite the fact that they were not considered

Table 2. Least squares means and sample size (n) of profit, production, longevity, and fertility traits ${ }^{1}$ according to foot angle score

\begin{tabular}{|c|c|c|c|c|c|c|c|c|c|c|c|c|c|}
\hline \multirow{2}{*}{$\begin{array}{l}\text { Foot } \\
\text { angle }^{2}\end{array}$} & \multicolumn{9}{|c|}{ Profit, production, and longevity traits } & \multicolumn{4}{|c|}{ Fertility traits } \\
\hline & $\mathrm{n}$ & PROF & M305 & FHL & NL & DIM & $\% \mathrm{DIM}$ & DD & $\mathrm{DD}_{a d j}$ & $\mathrm{n}$ & CI & ANI & $\mathrm{CI}_{a d j}$ \\
\hline 1 & 558 & $2^{\mathrm{c}}$ & $5,639^{\mathrm{cd}}$ & $1,276^{\mathrm{b}}$ & $3.4^{\mathrm{bc}}$ & 322 & $86.7^{\mathrm{a}}$ & $59^{\mathrm{a}}$ & $58^{\mathrm{ab}}$ & 247 & 405 & 1.67 & 410 \\
\hline 2 & 2,465 & $28^{\mathrm{bc}}$ & $5,718^{\mathrm{c}}$ & $1,318^{b}$ & $3.5^{\mathrm{c}}$ & 321 & $86.4^{\mathrm{a}}$ & $58^{\mathrm{b}}$ & $57^{\mathrm{b}}$ & 1,021 & 411 & 1.82 & 415 \\
\hline 3 & 6,441 & $34^{\mathrm{bc}}$ & $5,737^{\mathrm{c}}$ & $1,357^{\mathrm{ab}}$ & $3.6^{\mathrm{abc}}$ & 320 & $85.8^{\mathrm{b}}$ & $61^{\mathrm{a}}$ & $60^{\mathrm{ab}}$ & 2,708 & 409 & 1.77 & 413 \\
\hline 4 & 11,722 & $40^{\mathrm{b}}$ & $5,774^{\text {ac }}$ & $1,362^{\mathrm{ab}}$ & $3.6^{\mathrm{abc}}$ & 320 & $86.0^{\mathrm{a}}$ & $62^{\mathrm{a}}$ & $60^{\mathrm{ab}}$ & 4,628 & 407 & 1.78 & 411 \\
\hline 5 & 13,733 & $34^{\mathrm{bc}}$ & $5,771^{\text {ac }}$ & $1,362^{\mathrm{ab}}$ & $3.6^{\mathrm{abc}}$ & 319 & $85.9^{b}$ & $63^{\mathrm{a}}$ & $61^{\mathrm{a}}$ & 5,409 & 408 & 1.78 & 413 \\
\hline 6 & 17,005 & $52^{\mathrm{a}}$ & $5,826^{\text {abd }}$ & $1,382^{\mathrm{a}}$ & $3.7^{\mathrm{a}}$ & 320 & $85.9^{b}$ & $62^{\mathrm{a}}$ & $61^{\mathrm{a}}$ & 6,584 & 408 & 1.80 & 412 \\
\hline 7 & 8,664 & $52^{\mathrm{a}}$ & $5,859^{b}$ & $1,379^{\mathrm{a}}$ & $3.7^{\mathrm{a}}$ & 320 & $85.8^{\mathrm{b}}$ & $62^{\mathrm{a}}$ & $60^{\mathrm{ab}}$ & 3,295 & 408 & 1.80 & 412 \\
\hline 8 & 1,446 & $73^{\mathrm{a}}$ & $5,893^{\text {ab }}$ & $1,384^{\mathrm{a}}$ & $3.7^{\mathrm{ac}}$ & 320 & $85.7^{\mathrm{b}}$ & $64^{\mathrm{a}}$ & $62^{\mathrm{a}}$ & 569 & 408 & 1.76 & 411 \\
\hline 9 & 258 & $57^{\mathrm{abc}}$ & $5,772^{\text {abd }}$ & $1,348^{\mathrm{ab}}$ & $3.6^{\mathrm{abc}}$ & 314 & $85.9^{\mathrm{a}}$ & $60^{\mathrm{a}}$ & $58^{\mathrm{ab}}$ & 100 & 406 & 1.73 & 412 \\
\hline $\mathrm{RSD}^{3}$ & & 357 & 1,441 & 628 & 1.5 & 48 & 7.1 & 27 & 27 & & 49 & 0.93 & 48 \\
\hline
\end{tabular}

${ }^{\mathrm{a}-\mathrm{d}}$ Means within columns with different superscripts differ $(P<0.05)$

${ }^{1}$ Traits: $\mathrm{PROF}=$ profit; $\mathrm{M} 305=305-\mathrm{d}$ milk yield in first lactation; $\mathrm{FHL}=$ functional herd life; NL = number of lactations; DIM = average DIM; \%DIM = percentage of DIM; DD = average dry days; $\mathrm{DD}_{a d j}=$ average dry days adjusted by production; $\mathrm{CI}=$ average calving interval; $\mathrm{ANI}=$ average number of inseminations per lactation; and $\mathrm{CI}_{a d j}=$ average calving interval adjusted by production.

${ }^{2}$ Foot angle: from 1 (very low angle) to 9 (very steep).

${ }^{3}$ Residual standard deviation. 
Table 3. Least-squares means and sample size (n) of profit, production, longevity, and fertility traits ${ }^{1}$ according to rear legs set score

\begin{tabular}{|c|c|c|c|c|c|c|c|c|c|c|c|c|c|}
\hline \multirow{2}{*}{$\begin{array}{l}\text { Rear } \\
\text { legs } \\
\text { set }^{2}\end{array}$} & \multicolumn{9}{|c|}{ Profit, production, and longevity traits } & \multicolumn{4}{|c|}{ Fertility traits } \\
\hline & $\mathrm{n}$ & PROF & M305 & FHL & NL & DIM & $\% \mathrm{DIM}$ & $\mathrm{DD}$ & $\mathrm{DD}_{a d j}$ & $\mathrm{n}$ & $\mathrm{CI}$ & ANI & $\mathrm{CI}_{a d j}$ \\
\hline 1 & 151 & $-65^{\mathrm{e}}$ & $5,581^{\mathrm{cd}}$ & $1,284^{\mathrm{ab}}$ & $3.4^{\mathrm{ac}}$ & 317 & $86.2^{\mathrm{ab}}$ & 58 & 57 & 63 & $403^{\mathrm{ae}}$ & 1.69 & 409 \\
\hline 2 & 800 & $5^{\mathrm{de}}$ & $5,575^{\mathrm{d}}$ & $1,353^{\mathrm{ab}}$ & $3.6^{\mathrm{abc}}$ & 320 & $86.3^{\mathrm{ab}}$ & 59 & 57 & 342 & $401^{\mathrm{de}}$ & 1.78 & 408 \\
\hline 3 & 2,979 & $4^{\mathrm{e}}$ & $5,697^{\mathrm{cd}}$ & $1,340^{\mathrm{ab}}$ & $3.6^{\mathrm{abc}}$ & 317 & $85.9^{\mathrm{ab}}$ & 63 & 61 & 1,172 & $407^{\text {ade }}$ & 1.78 & 412 \\
\hline 4 & 6,583 & $34^{\mathrm{bcd}}$ & $5,789^{\text {ac }}$ & $1,370^{\mathrm{ab}}$ & $3.6^{\mathrm{ab}}$ & 320 & $85.9^{\mathrm{ab}}$ & 62 & 60 & 2,406 & $408^{\mathrm{ac}}$ & 1.81 & 412 \\
\hline 5 & 12,989 & $51^{\mathrm{ab}}$ & $5,811^{\mathrm{ab}}$ & $1,380^{\mathrm{a}}$ & $3.7^{\mathrm{a}}$ & 319 & $85.8^{\mathrm{ab}}$ & 63 & 61 & 4,489 & $407^{\text {bce }}$ & 1.78 & 411 \\
\hline 6 & 23,489 & $52^{\mathrm{a}}$ & $5,829^{a}$ & $1,376^{\mathrm{a}}$ & $3.7^{\mathrm{a}}$ & 320 & $85.8^{\mathrm{b}}$ & 62 & 61 & 8,048 & $409^{\mathrm{ab}}$ & 1.78 & 413 \\
\hline 7 & 12,315 & $40^{\mathrm{abcd}}$ & $5,774^{\mathrm{bc}}$ & $1,348^{\mathrm{b}}$ & $3.6^{\mathrm{bc}}$ & 320 & $86.1^{\mathrm{a}}$ & 61 & 59 & 4,424 & $408^{\mathrm{a}}$ & 1.78 & 412 \\
\hline 8 & 2,509 & $24^{\text {cde }}$ & $5,685^{\mathrm{cd}}$ & $1,325^{\mathrm{b}}$ & $3.5^{\mathrm{c}}$ & 320 & $86.1^{\mathrm{ab}}$ & 60 & 59 & 1,004 & $411^{\mathrm{a}}$ & 1.80 & 415 \\
\hline 9 & 477 & $-20^{\mathrm{e}}$ & $5,587^{\mathrm{cd}}$ & $1,301^{\mathrm{ab}}$ & $3.5^{\mathrm{ac}}$ & 320 & $86.5^{\mathrm{ab}}$ & 61 & 60 & 200 & $416^{\mathrm{a}}$ & 1.79 & 419 \\
\hline $\mathrm{RSD}^{3}$ & & 357 & 1,441 & 628 & 1.5 & 48 & 7.1 & 27 & 27 & & 49 & 0.93 & 48 \\
\hline
\end{tabular}

${ }^{\mathrm{a}-\mathrm{e}}$ Means within columns with different superscripts differ $(P<0.05)$.

${ }^{1}$ Traits: PROF = profit; M305 = 305-d milk yield in first lactation; FHL = functional herd life; NL = number of lactations; DIM = average DIM; \% DIM = percentage of DIM; DD = average dry days; $\mathrm{DD}_{a d j}=$ average dry days adjusted by production; $\mathrm{CI}=$ average calving interval; $\mathrm{ANI}=$ average number of inseminations per lactation; and $\mathrm{CI}_{a d j}=$ average calving interval adjusted by production.

${ }^{2}$ Rear legs set: From 1 (straight) to 9 (sickled).

${ }^{3}$ Residual standard deviation.

as repeated measures but rather as averages across lactations.

Genetic Correlations. Among the 3 locomotion traits, a positive genetic correlation was found (0.73) between FL and FA, but RLS had negative correlations $(-0.39$ and -0.44$)$ with those traits, respectively. Similar results were reported in the literature (Boelling and Pollott, 1998b; Pérez-Cabal, 2002; Wiggans et al., 2004). Feet and legs was the most correlated locomotion trait to PROF (0.10), whereas FA and RLS were almost uncorrelated, similar to those found in the Spanish dairy population (Pérez-Cabal and Alenda, 2002). The locomotion trait most correlated to milk production was RLS (0.12), whereas FL and FA showed values close to zero.

Despite reports of moderate or high correlations among FL, FA, RLS, and longevity traits elsewhere (Vollema and Groen, 1997; De Jong et al., 1999), genetic correlations in this study were low ( -0.10 to 0.05$)$. Furthermore, genetic correlations were somewhat different for CI and ANI in our study. Calving interval had higher correlations with FA and FL (0.17 and 0.12, respectively) than ANI (0.07 and 0.05, respectively). Pryce et al. (2000) obtained a negative correlation of CI with FA $(-0.20)$, but positive with RLS (0.19). Their study found that a slight deterioration in fertility occurred in animals with higher FL and FA scores, as well as little genetic repercussion for longevity, production, and, therefore, profit.

\section{Relationships Among Breeding Values}

Linear and quadratic regressions for PROF adjusted for production (using EBV of M305 and 305-d fat and protein yields in first lactation) and unadjusted, as well as M305 and FHL, with respective coefficients of determination are shown in Table 5. Slopes of linear fits were in accordance with genetic correlations because BLUP methodology assumes linear relationships. It should be noted that all cases were best explained by significant (although weak) quadratic relationships. The highest PROF variability explained by locomotion

Table 4. Heritability $\left(\mathrm{h}^{2}\right)$ and genetic correlations $\left(\rho_{\mathrm{g}}\right)$ of feet and legs $(\mathrm{FL})$, foot angle (FA), and rear legs set (RLS), profit (PROF), 305-d milk in first lactation (M305), productive life (PL), functional herd life (FHL), average calving interval (CI), and average number of inseminations per lactation (ANI)

\begin{tabular}{|c|c|c|c|c|c|c|c|c|}
\hline & $\mathrm{h}^{2}$ & $\mathrm{SE}$ & $\rho_{\mathrm{g}} \mathrm{FL}$ & $\mathrm{SE}$ & $\rho_{\mathrm{g}} \mathrm{FA}$ & $\mathrm{SE}$ & $\rho_{\mathrm{g}} \mathrm{RLS}$ & $\mathrm{SE}$ \\
\hline FL & 0.14 & 0.007 & - & - & 0.73 & 0.020 & -0.39 & 0.030 \\
\hline FA & 0.12 & 0.007 & 0.73 & 0.020 & - & - & -0.44 & 0.032 \\
\hline RLS & 0.19 & 0.008 & -0.39 & 0.030 & -0.44 & 0.032 & - & - \\
\hline PROF & 0.20 & 0.009 & 0.10 & 0.033 & 0.05 & 0.036 & 0.04 & 0.032 \\
\hline M305 & 0.34 & 0.009 & 0.06 & 0.028 & -0.01 & 0.029 & 0.12 & 0.026 \\
\hline PL & 0.10 & 0.007 & 0.05 & 0.045 & 0.03 & 0.049 & -0.09 & 0.010 \\
\hline FHL & 0.10 & 0.007 & 0.05 & 0.054 & 0.03 & 0.044 & -0.10 & 0.040 \\
\hline $\mathrm{CI}$ & 0.04 & 0.005 & 0.12 & 0.054 & 0.17 & 0.059 & 0.07 & 0.051 \\
\hline ANI & 0.04 & 0.006 & 0.05 & 0.072 & 0.07 & 0.015 & 0.08 & 0.066 \\
\hline
\end{tabular}




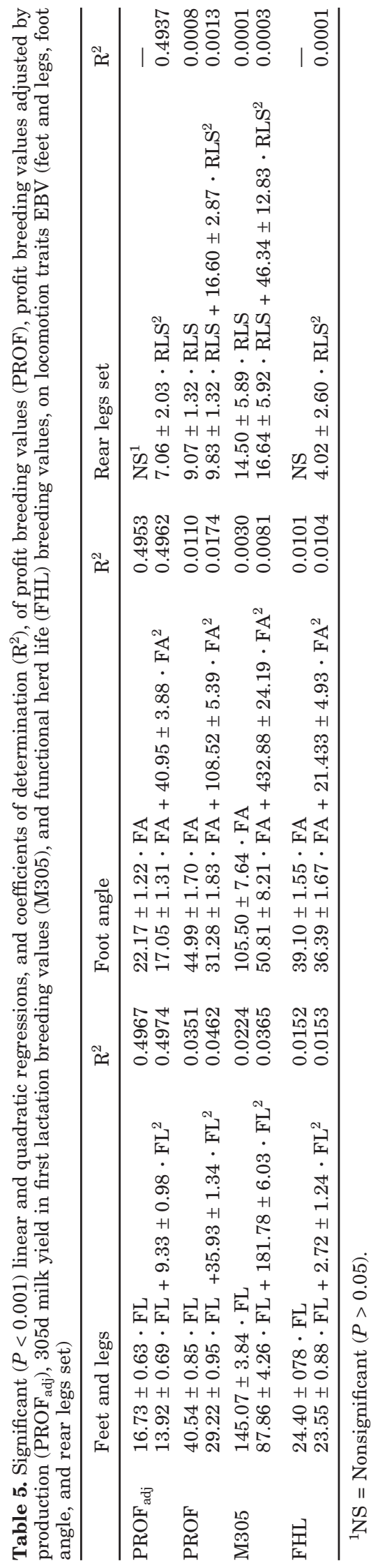

traits were obtained for quadratic regressions on FL, with a coefficient of determination of 0.4974 when production traits were included in the model as covariates. In this case, the magnitude of quadratic coefficients for FA was much larger than for FL. However, coefficients of determination for both models, and for RLS, were similar (almost 0.50) and small differences regarding respective linear models were found (although the cross-validation confirmed the quadratic fits).

The regressions of PROF unadjusted showed small coefficients of determination. However, they were slightly higher than those obtained for FHL. For this trait, statistically significant linear and quadratic coefficients were also found for FL, FA, and RLS. Surprisingly, low coefficients of determination were obtained despite the fact that locomotion problems are an important reason for culling (Sattler, 2002). Cows considered in this study might have been culled because of reasons other than bad conformation of feet and legs, and therefore, locomotion traits by themselves do not seem to be good indicators of FHL. This suggests that locomotion traits are related to PROF by reasons other than functionality such as production, as regressions of M305 showed in Table 5. In relation to FHL, other researchers reported varied results. Pérez-Cabal and Alenda (2002) found only linear regression was the best fit for FA, and Dekkers et al. (1994) reported positive quadratic relationships between FHL and FL for grade Canadian dairy cows, but negative quadratic and cubic trends in joint grade and registered analyses. In the same study, however, only linear coefficients were found to be statistically significant for RLS.

Significant quadratic relationships of EBV for each of the 3 locomotion traits and EBV of PROF, unadjusted and adjusted for production, and FHL are shown in Figure 1. For both PROF cases, the quadratic fit for FA seemed to have the highest influence on PROF, whereas RLS EBV showed little relation to PROF EBV (even more, linear regression for PROF adjusted was not significant). This could be explained because, among the 3 locomotion traits, FA refers to hoof morphology whereas RLS refers to leg conformation, and FL is a global trait. As Boettcher and Dekkers (1997) pointed out, hoof conformation is directly linked to locomotion diseases, and therefore, would affect profitability.

With respect to PROF adjusted for production, positive EBV for FL were associated with positive EBV for PROF. In fact, EBV for FL from -2 to 0 were generally related to zero PROF EBV, and only animals with positive EBV of FL would transmit positive PROF to their offspring. A cow with an EBV of +2 for FL would transmit half of $\$ 72$ per year instead of half of $\$ 25$ per year for a cow with an EBV of +1 for FL. Surprisingly, extreme EBV for FA and RLS were related to higher 


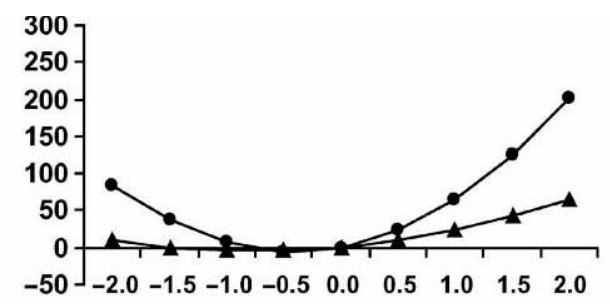

Feet and legs EBV
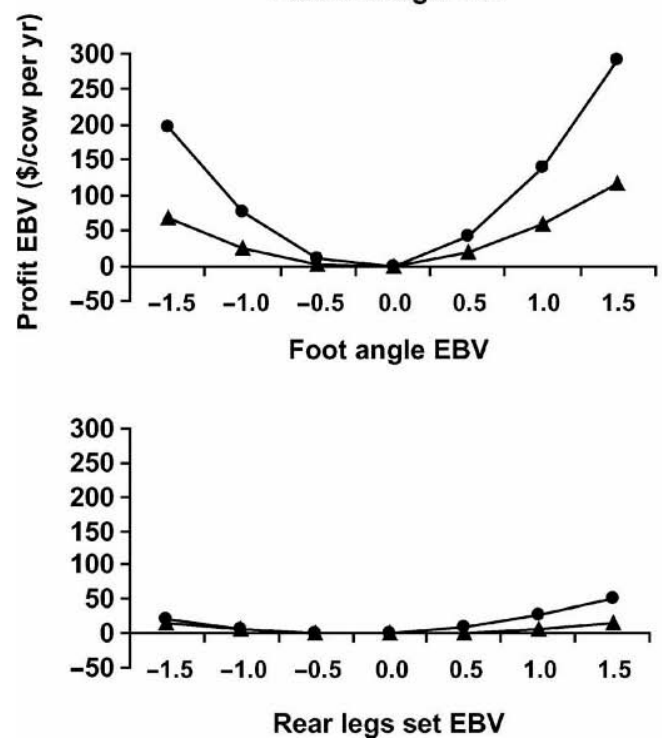
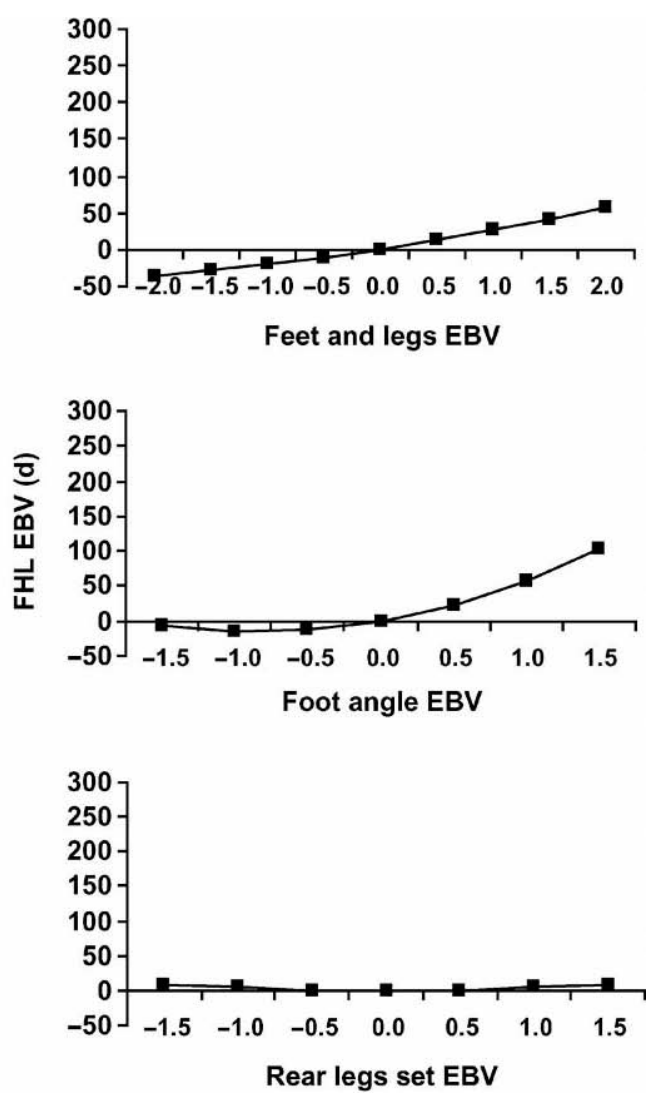

Figure 1. Significant quadratic relationships between EBV of locomotion traits and EBV of profit ( $)$, EBV of profit adjusted for production $(\mathbf{\Lambda})$, and EBV of functional herd life (FHL, $\mathbf{\square})$.

PROF EBV, in opposition to the intermediate optima for FA and RLS considered in official genetic evaluations. Pérez-Cabal and Alenda (2002) obtained smaller differences between the quadratic coefficients for FA and FL; the shape of the quadratic RLS curve was the opposite of the one presented in our study.

\section{CONCLUSIONS}

The emphasis placed by dairy producers on locomotion traits in a breeding program was clearly supported by the phenotypic results of our study. Cows with higher FL scores and intermediate FA and RLS scores showed better performance in terms of production and longevity. The genetic results, however, provided limited support for that emphasis. Only FL was consistent with the generally accepted optimum EBV range because the best EBV for FL had a significant effect on PROF and FHL. In addition, locomotion traits had low heritability, but some genetic variability. Furthermore, genetic correlations between FHL and the locomotion traits were close to zero, although locomotion is commonly considered one of the most important reasons for culling.
To obtain a higher genetic response in a breeding program, the residual variability could be reduced considering complementary information to the locomotion type traits. Systematic recording of feet and legs diseases would help in differentiating among reasons for culling (e.g., locomotion diseases or conformation faults), and thereby, relationships between feet and legs conformation and FHL could be more properly approached. Moreover, the costs of locomotion disorders could be quantified and included in PROF calculations to determine more accurately the genetic relationships between locomotion and profitability.

\section{ACKNOWLEDGMENTS}

Authors would like to thank the Navarra and Basque Holstein Associations for providing the data. Research was supported by project CDTI (P030250390).

\section{REFERENCES}

Boelling, D., and G. E. Pollott. 1998a. Locomotion, lameness, hoof and leg traits in cattle. I. Phenotypic influences and relationships. Livest. Prod. Sci. 54:193-203. 
Boelling, D., and G. E. Pollott. 1998b. Locomotion, lameness, hoof and leg traits in cattle. II. Genetic relationships and breeding values. Livest. Prod. Sci. 54:205-215.

Boettcher, P. J., and J. C. M. Dekkers. 1997. Indirect selection for resistance to locomotive disorders in dairy cattle. Proc. Int. Workshop on Genetic Improvement of Functional Traits in Cattle; Health, Uppsala, Sweden. Interbull Bull. 15:123-129.

Boettcher, P. J., J. C. M. Dekkers, L. D. Warnick, and S. J. Wells. 1998. Genetic analysis of clinical lameness in dairy cattle. J. Dairy Sci. 81:1148-1156.

Booth, C. J., L. D. Warnick, Y. T. Gröhn, D. O. Maizon, C. L. Guard, and D. Janssen. 2004. Effect of lameness on culling in dairy cows. J. Dairy Sci. 87:4115-4122.

De Jong, G., A. R. Vollema, S. Van Der Beek, and A. Harbers. 1999. Breeding value for functional longevity in the Netherlands. Proc. Int. Workshop on EU Concerted Action Genetic Improvement of Functional Traits in Cattle; Longevity. Jouy-en-Josas, France. Interbull Bull. 21:68-72.

Dekkers, J. C. M., L. K. Jairath, and B. H. Lawrence. 1994. Relationships between sire genetic evaluation for conformation and functional herd life of daughters. J. Dairy Sci. 77:844-854.

Fatehi, J., A. Stella, J. J. Shannon, and P. J. Boettcher. 2003. Genetic parameters for feet and legs traits evaluated in different environments. J. Dairy Sci. 86:661-666.

González-Recio, O., and R. Alenda. 2005. Genetic parameters for female fertility traits and a fertility index in Spanish dairy cattle. J. Dairy Sci. 88:3282-3289.

Green, L. E., V. J. Hedges, Y. H. Schukken, R. W. Blowey, and A. J. Packington. 2002. The impact of clinical lameness on the milk yield of dairy cows. J. Dairy Sci. 85:2250-2256.

Groeneveld, E., and L. A. García Cortés. 1998. VCE 4.0, A (co)variance component package for frequentists and Bayesians. Proc. 6th. World Congr. Genet. Appl. Livest. Prod. 27:455-456.

Jairath, L., J. C. M. Dekkers, L. R. Schaeffer, Z. Liu, E. B. Burnside, and B. Koldstad. 1998. Genetic evaluation for herd life in Canada. J. Dairy Sci. 81:550-562.

Kossaibati, M. A., R. J. Esslemont, and C. Watson. 1999. The cost of lameness in dairy herds. National Cattle Lameness Conference, Stoneleigh, UK. Available: http://www.rdg.ac.uk/AcaDepts/aa/ DAISY/DAISY1/Lamenesscost.htm

McDaniel, B. T. 1997. Breeding programs to reduce foot and leg problems. Proc. Int. Workshop on Genetic Improvement of Func- tional Traits in Cattle; Health. Uppsala, Sweden. Interbull Bull. 15:115-122.

National Animal Health Monitoring System. 2002. Dairy 2002. Part I: Reference of dairy health and management in the United States. Available: http://www.aphis.usda.gov/vs/ceah/ncahs/nahms/ dairy/dairy02/Dairy02Pt1.pdf

Norman, H. D., R. L. Powell, J. R. Wright, and R. E. Pearson. 1996. Phenotypic relationship of yield and type scores from first lactation with herd life and profitability. J. Dairy Sci. 79:689-701.

Pérez-Cabal, M. A. 2002. Predicción de la rentabilidad en el ganado vacuno lechero en España. Tesis Doctoral. Escuela Técnica Superior de Ingenieros Agrónomos, Universidad Politécnica de Madrid, Spain

Pérez-Cabal, M. A., and R. Alenda. 2002. Genetic relationships between lifetime profit and type traits in Spanish Holstein cows. J. Dairy Sci. 85:3480-3491.

Pérez-Cabal, M. A., and R. Alenda. 2003. Lifetime profit as an individual trait and prediction of its breeding values in Spanish Holstein cows. J. Dairy Sci. 86:4115-4122.

Pryce, J. E., M. P. Coffey, and S. Brotherstone. 2000. The genetic relationships between calving interval, body condition score, and linear type and management traits in registered Holsteins. J. Dairy Sci. 83:2664-2671.

SAS Institute. 2001. User's Guide, Release 8.2. SAS Institute Inc., Cary, NC.

Sattler, J.D. 2002. The importance of locomotion. Midwest DairyBusiness November:32-34.

Smith, L. A., B. G. Cassell, and R. E. Pearson. 1998. The effects of inbreeding on the lifetime performance of dairy cattle. J. Dairy Sci. 81:2729-2737.

Van Dorp, T. E., P. Boettcher, and L. R. Schaeffer. 2004. Genetics of locomotion. Livest. Prod. Sci. 90:247-253.

Veerkamp, R. F., E. P. C. Koenen, and G. De Jong. 2001. Genetic correlations among body condition score, yield, and fertility in first-parity cows estimated by random regression models. J. Dairy Sci. 84:2327-2335.

Vollema, A. R., and A. F. Groen. 1997. Genetic correlations between longevity and conformation traits in an upgrading dairy cattle population. J. Dairy Sci. 80:3006-3014.

Warnick, L. D., D. Janssen, C. L. Guard, and Y. T. Gröhn. 2001. The effect of lameness on milk production in dairy cows. J. Dairy Sci. 84:1988-1997.

Wiggans, G. R., N. Gengler, and J. R. Wright. 2004. Type trait (co)variance components for five dairy breeds. J. Dairy Sci. 87:2324-2330. 